\title{
Study of some biochemical parameters of vitiligo patients in Bangladesh
}

\author{
Md. Ziaul Amina*, Mohd. Hafizur Rahman ${ }^{\mathrm{b}}$ and Mohammed A. Satter \\ ${ }^{a}$ Department of Genetic Engineering and Biotechnology; Jessore Science and Technology University, \\ Jessore-7408; ${ }^{b}$ Department of Biochemistry, Dhaka Medical College, Dhaka and \\ ${ }^{c}$ Institute of Food Science and Technology, BCSIR, Dhaka, Bangladesh
}

\begin{abstract}
This study is focus on the biochemical analysis to investigate the condition of different biochemical parameters for the Vitiligo patients. This biochemical analysis deals with the blood serum level of random blood sugar, bilirubin, urea, total protein, SGOT, SGPT, alkaline phosphatase, total cholesterol and uric acids. The increasing some of the biochemical parameters were statistically significant with the age groups. Random blood sugar analysis of the 125 patient's age group 31- 40, 41- 50 and above 50 significantly higher than the control group. No significant changes were observed in serum bilirubin, serum urea, serum creatinine, serum alkaline phosphatase (ALP) and serum asparate amino transferase (AST) level in different age group of Vitiligo patients. In this study, the serum total proteins were slightly decreased in the age group patients below 10 and 11-20 as compared to healthy controls. The average serum total protein level of the below 10 and 11-20 age group patients were $5.31 \mathrm{~g} / \mathrm{dl}$ and $6.50 \mathrm{~g} / \mathrm{dl}$ respectively, whereas the controls were $5.95 \mathrm{~g} / \mathrm{dl}$ and $6.92 \mathrm{~g} / \mathrm{dl} \mathrm{respectively}$. Serum cholesterol, serum triglycerides and serum uric acid levels were significantly changed in the age group 11-20 and 31-40 compared with the healthy control. The average serum cholesterol level, triglyceride (TG) level and uric acid level were $152.17 \mathrm{mg} / \mathrm{dl}, 90.27 \mathrm{mg} / \mathrm{dl}$, $4.75 \mathrm{mg} / \mathrm{dl}$ and $173.40 \mathrm{mg} / \mathrm{dl}, 149.95 \mathrm{mg} / \mathrm{dl}, 5.54 \mathrm{mg} / \mathrm{dl}$ respectively for the patients of 11-20 and 31-40 years age group. The controls of these parameters for the 11-20 years and 31-40 years age groups were $150.57 \mathrm{mg} / \mathrm{dl}, 94.41 \mathrm{mg} / \mathrm{dl}, 4.28 \mathrm{mg} / \mathrm{dl}$ and $156.75 \mathrm{mg} / \mathrm{dl}, 101 \mathrm{mg} / \mathrm{dl}$, $4.77 \mathrm{mg} / \mathrm{dl}$ respectively. These biochemical studies on Vitiligo indicated that there was no significant changed observed in some biochemical parameters in the different age group of Vitiligo patients but some biochemical parameters like total protein, total cholesterol, triglycerides (TG), uric acid and random blood sugar level were significantly changed in different age group of Vitiligo patients specially among the 11-20 and 31-40 years age group. This biochemical studies would be helpful to know details about the pathological condition of the Vitiligo patients associated with other disease.
\end{abstract}

Key word: Vitiligo, ALP, AST and TG levels

\section{Introduction}

Vitiligo is one of the most common skin disorders affecting approximately $1-2 \%$ of world population with cosmetically and psychologically devastating effects (http//www. answers.com/topic/vitiligo). The destruction of melanocytes is the cause of depigmented maculae that clinically represents the disease Vitiligo. The condition occurs when pigmented cells are destroyed, causing patches of skin to lose their normal color and appear whiter (Alkhateeb et al. 2003, Lacovelli et al 2003).

In Vitiligo an acquired idiopathic disorder occurred in which there are depigmented macules of variable size with enlarge and coalesce to from extensive areas of leucoderma (Dawber et al 1970. Vitiligo patients can often attribute the onset of their disease to a specific life event or crisis or illness.

Different theories suggest that autoimmune, genetic disorders, toxic metabolites, and oxidative stimuli are the main factors causing Vitiligo The nervous system and or the absence of the melanocyte growth factor may be included (Ongenaek et al. 2003). Various studies on Vitiligo suggest that there is a significant association between Vitiligo and other disease

The most frequently associated disease is thyroid disease, diabetes mellitus, pernicious anemia, Addisons disease and appear more commonly than reasonably expected. Thyroid disease particularly hyperthyroidism, hypothyroidism, Groups disease, toxic goiter and thyroiditis (Dawber et al. 
1970) may also be found, it up 30 to 40 percent (Howanitz et al. 1981). It has been reported that the thyroid function has been elevated in women and children (Amin et al 2008). Diabetes mellitus both juvenile and adult onset types occur in 1 to 7.1 percent of Vitiligo patients and conversely, Vitiligo occurs in 4.8 percent of diabetes patients (Ghoeum et al. 1987). Pernicious anemia, although uncommonly occurs with increased frequently in Vitiligo patients. Among with pernicious anemia, Vitiligo has been documented in 1.6 to 10.6 percent (Barnes et al. 1988, Lerner et al. 1984, Bystryn et al. 1987, Nordlund et al. 1987, Ghoneum et al. 1987 and Grimes et al. 1986).

Grunnet et al. 1970 and Dawber et al. 1970 reported that diabetes mellitus, pernicious anemia, Addisons disease and thyroiditis are most wide spread in Vitiligo and pernicious anemia is more common among those with late-onset Vitiligo. Althrough neither of these observation has been confirmed but the incidence of gastric achlorhydria and atrophic gastritis are increased among those with Vitiligo (Burns et al. 1972)..

The incidence of Addisons disease in Vitiligo is reported to 2 percent and is likely much less common. But adrenal cortex and steroid-cell antibodies do not appear to much increased in Vitiligo patients (Burns et al. 1972).

There are no histologic findings to diagnostic of Vitiligo. However, in dermis, lymphocytes are present in the upper dermis in evolving macules and in inflammatory Vitiligo. Melanin may be present in dermal macrophages in darker skin types. Dopa studies have demonstrated the dynamic nature of evolution of Vitiligo (Hann et al.1996).

With electron microscopy studies reveal that there are degenerative changes in melanocytes and keratinocytes in the active margin of the lesions. The melanocytes have few melanosomes, which are usually rounded and have a finely granular inner structure. Melanocytes become less dendritic, and an intercellular space develops between melanocytes and keratinocytes ( Ortonne et al. 1983).

In tissue cultures, melanocytes tend to grow poorly and to die prematurely. Melanocytes cultured from the margins demonstrate cytoplasmic vacuolization, melanosome aggregation, autophagic vacuoles, pynknosis and fatty degeneration (Lerner et al. 1959).
Vitiligo associated with viral encephalitis and Vitiligo with multiple sclerosis and Horners syndrome . Onset of Vitiligo following a period of emotional stress and the quasidermatomal pattern of segmental Vitiligo are also supportive observations. Degenerative and regenerative nerve cell changes have been noted in the center and the periphery of depigmented macules. Increased sweating, increased surface temperature and increased bleeding times have been described in Vitiligo macules (Thomas Fitzatrick et al. 1999).

The biochemical basis of the neural hypothesis may also reveal the causes of Vitiligo. Such as acetylcholine causes depigmentation and has been demonstrated to have an inhibitory effect on marginal melanocytes in Vitiligo patients. Furthermore, acetylcholine esterase activity has been shown to be absent in depigmenting skin but present in repigmenting skin. Epinephrine levels have also been found markedly decreased in involved skin but normal in normal skin. Nor-epinephrine has been found increased fourfold in lesional skin and twofold in nonlesional skin (Bolognia et al.1988).

Vitiligo is associate with various types of disease. Some microscopic and pathological techniques have been used to applied for the clinical diagnosis of Vitiligo but no finding have still been developed. Althrough biochemical hypothesis have been applied to the Vitiligo patients but the study of biochemical parameters have not yet been carried out for the Vitiligo patients. Therefore, the present study focused on the investigation of some biochemical parameters like blood sugar, serum bilirubin, serum urea, serum total protein, serum SGPT, serum ALT, serum alkaline phosphatase, serum total cholesterol and serum uric acid level in the blood of the Vitiligo patient. These investigation may have diagnostic and therapeutic importance for the Vitiligo patients .

\section{Materials and Methods}

\section{Study area}

Biochemical parameters of the Vitiligo patients were analyzed in a wide range in this study. Rajshahi and the surrounding district of Rajshahi in Bangladesh such as Natore, Bogra, Nawabganj, Rangpur, Dinajpur, Nilfamari, Pabna, Kushtia, Naogaon. Kurigram, Lalmonirhat and Sirajganj etc. The study was carried out among 125 patients who were having depigmented vitiligoinous lesions attending the Skin and Venereal disease out patient's department of Skin and 
Venereal disease in Rajshahi Medical College Hospital, Rajshahi, Bangladesh from 1999 to 2002 and investigations were undertaken immediately, there after. This study included 125 individuals during entire period of investigation. One hundred twenty five healthy human subjects including child, adolescent, young and old were chosen as control. Twentyfive patients ( 10 male and 15 female) were selected from the 125 patients who were over 40 years of age and were diagnosed by a qualified Dermatologist to have Vitiligo.

\section{Collection of sample}

Blood sample $(\mathrm{n}=125)$ were collected from the staff andstudents of the Rajshahi Medical College and hospital and out patients attendingin the Skin and Veneral disease department of Rajshahi Medical College Hospital. A details history was recorded in a pre-set proforms.

\section{Serology}

Serological study were performed in the department of Biochemistry, Rajshahi Medical College, department of Biochemistry, Rajshahi University and Medipath diagnostic complex, Rajshahi are equipped with apparatus, reagent, equipment and other facilities to carry out this study. In this study, the biochemical analyzer ACTO-1, Italy Digital photoelectric colorimeters were mainly used for the analysis of blood sugar, serum bilirubin, serum urea, serum creatinine, serum total protein, serum ALT/SGPT, serum alkaline phosphate, serum aspirate aminotransferase, serum total cholesterol level, serum triglyceride level, serum high density-lipo protein and serum uric acid. The standard method for each analysis were performed as follows:

\section{Estimation of blood sugar}

Blood sugar were estimated by enzymatic, colorimetric (GOD-PAP) method without deproteinisation. The method was based on the principles of glucose oxidase/peroxidase method of Trinder (1969). Serum was used for glucose estimation with all aseptic precautions, $5 \mathrm{ml}$ of venous blood was taken in a clear dry test tube, and allowed to stand at room temperature until it had clotted. After blood were centrifuged at a speed $2500 \mathrm{rpm}$ for 5 minutes. Serum was separated within 30 minutes.

\section{Procedure}

$12 \times 75 \mathrm{~mm}$ borosilicate glass tube were taken and labeled as B for blank, S for standard, C for quality control serum and
Experimental. For experimental serum with accurate micropipette $1.0 \mathrm{ml}$ of GOD-PAP reagent was pipette into each tube and $0.01 \mathrm{ml}(10 \mu \mathrm{l})$ of standard. Control and experimental serum were added to the tubes labeled as B, C and Ex., respectively. The contents of the each tube were mixed properly and then incubated for 5 minutes at $37^{\circ} \mathrm{C}$. The absorbance (A) of the standard, control and experimental samples were measured against the reagent blank at $505 \mathrm{~nm}$ within 60 minutes. Two parallel experiments were carried out for each sample. The biochemical analyzer used in this study had the advantage that the read of the absorbance of the blank, standard and the sample performed necessary calculation and printed out the result.

\section{Estimation of serum bilirubin}

Serum bilirubin was determined by Diazo- method. In this method bilirubin in the presence of sulphanilic acid diazonium salt forms red colored azo-compound in alkaline solution. The total bilirubin in serum was determined using the method of Jendrassik and Graf by coupling it with diazotized sulphanilic acid after addition of DMSO (dimethyl sulfoxide).

\section{Procedure}

$12 \times 75 \mathrm{~mm}$ borosilicate glass tube were taken and labeled as B for blank, and Ex. for experimental. Serum with accurate micropipette $1.5 \mathrm{ml}$ of reagent was pipette into each tube and $0.05 \mathrm{ml}(50 \mu \mathrm{l})$ of reagent 2 (sodium nitrite) was added to the tube labeled as Ex. Only leaving away the blank. $0.1 \mathrm{ml}(100$ $\mu 1)$ of the experimental sample was added to the both tubes and waited exactly 5 minutes at room temperature. The absorbance (A) of the experimental sample was measured against the sample blank at $550 \mathrm{~nm}$. The same procedure was followed for the quality control serum. Two parallel experiments were carried out for each sample.

\section{Estimation of serum urea}

Serum urea was estimated in this study by using urease method. In this method, urease hydrolyzed urea in the presence of water to ammonia and carbon dioxide. In this modified Berthelot reaction, the ammonium ions react with hypochlorite and salicylate to form a green dye. The absorbance (A) of the experimental sample was measured against the sample blank at $578 \mathrm{~nm}$. 


\section{Procedure}

$12 \times 75 \mathrm{~mm}$ borosilicate glass tube were taken and labeled as B for blank, S for standard, C for quality control serum and Ex. for experimental serum. $1.0 \mathrm{ml}$ of enzyme reagent 1a (working reagent) was pipette in each test tube and $0.01 \mathrm{ml}$ $(10 \mu \mathrm{l})$ of standard, control and experimental serum were added to the tubes labeled as S, C and Ex.1, Ex2, Ex 3 respectively. The content of the each tube were mixed properly and then incubated for 3 minutes at $37^{\circ} \mathrm{C} .1 \mathrm{ml}$ of the reagent 2 was added to each test tube and mixed properly, the mixture was then incubated for further 5 minutes at $37{ }^{\circ} \mathrm{C}$. The absorbance (A) of the standard, control and experimental samples were measured against the reagent blank at 600 $\mathrm{nm}$ within 60 minutes.

\section{Estimation of serum creatinine}

Serum creatinine was measure by kinetic method without deproteination by using photometric colorimetic test. The creatinine estimation was performed by using the standard protocol for the reagent kit, Creratinine liquicolor ( HumanGmbH, Germany).

\section{Estimation of serum total Protein}

Serum protein was estimated by Biuret method. In this method, cupric ions in an alkaline medium interact with protein peptide bonds resulting in the formation of a colored complex.

\section{Procedure}

$12 \mathrm{X} 75 \mathrm{~mm}$ borosilicate glass tube were taken and labeled as B for blank, S for standard, C for quality control serum and Ex. for experimental serum $1.0 \mathrm{ml}$ of reagent was pipette in each test tube and $0.02 \mathrm{ml}(20 \mu \mathrm{l})$ of standard. Control and experimental serum were added to the tubes labeled as $\mathrm{S}, \mathrm{C}$ and Ex. respectively. The content of the each tube were mixed properly and then incubated for 30 minutes at $20{ }^{\circ} \mathrm{C}$ to at $25^{\circ} \mathrm{C}$. The absorbance (A) of the standard, control and experimental samples were measured against the reagent blank at 530-570 nm within 30 minutes.

Estimation of serum ALT ( SPGT), alkaline phosphatase and asparate aminotransferase ( SGOT)

Serum alanine aminotransferase (ALT), alkaline phosphatase and asparate were determine by UV method. This is an optimized standard method according to the concentrations recommended by the IFCC.
Estimation of serum total cholesterol, triglycerides and high density lipoprotein (HDL)

Serum cholesterol, triglycerides and high density lipoprotein (HDL) were determined by enzymatic colorimetric (CHOD- PAP) methods. In this method cholesterol esterase hydrolyzes the ester cholesterol to free cholesterol. The enzyme cholesterol oxidase converts cholesterol into cholesterol 4-en-3-one with formation of hydrogen peroxide (Richmond 1972 and Flegg 1973). The formed hydrogen peroxide can be quantified by reacting with Trinders reagent 4 amino-pheonazone, phenol and peroxidase. A red quinoneimine dye is formed as indicator.

\section{Procedure}

$12 \times 75 \mathrm{~mm}$ borosilicate glass tube were taken and labeled as B for blank, S for standard, C for quality control serum and Ex. for experimental serum. With accurate micropipette 1.0 $\mathrm{ml}$ of working cholesterol reagent was pipette in each test tube and $0.01 \mathrm{ml}(10 \mu \mathrm{l})$ of standard, control and experimental serum were added to the tubes labeled as $\mathrm{S}, \mathrm{C}$ and Ex.1Ex2,Ex3. ...respectively. The content of the each tube were mixed properly and then incubated for 5 minutes at $37{ }^{\circ} \mathrm{C} .1 \mathrm{ml}$ of the reagent 2 was added to each test tube and mixed properly, the mixture was then incubated for further 5 minutes at $37{ }^{\circ} \mathrm{C}$. The absorbance (A) of the standard, control and experimental samples were measured against the reagent blank at $505 \mathrm{~nm}$ within 60 minutes. Two parallel experiments were carried out for each sample.

The serum triglyceride were measured by enzymatic -colorimetric (GPO - PAP) method by using the triglycerides GO liquicolor (Human-GmbH, Germany). The procedure used in the estimation of triglyceride was same as total cholesterol estimation. The serum HDL cholesterol was determined by phosphotungstate/Magnesium method (Burstein et al 1970).

\section{Estimation of serum uric acid}

Serum uric acid was estimated by Enzymatic colorimetric method by using the Standard protocol (Randox Laboratories, USA).

\section{Results and Discussion}

Vitiligo is a cosmopolitan disease throughout the world. In the present investigation various biochemical properties among the 125 Vitiligo patients were investigated. The 
patients volunteered in this study were randomly selected from the Skin and Venereal disease department, Medical college hospital, Rajshahi, Bangladesh during 1999-2002. The results obtained from these studies are discussed as follows.

In this study, we determined the random blood sugar level of the Vitiligo patients among different age group. The results of random blood sugar level of the different age groups of the Vitiligo patients and corresponding to their control groups have been presented in Table I. The average random blood sugar level of the below 10 years age group patients and control subjects were $77.50 \mathrm{mg} / \mathrm{dl}$ to $78.00 \mathrm{mg} / \mathrm{dl}$ respectively. The standard deviation $[\mathrm{SD} \pm$ ] of these results were 18.283 to 15.861 [ $\mathrm{t}$ value $=0.071$ ] respectively. age group patients were $101.38 \mathrm{mg} / \mathrm{dl}, 126.56, \mathrm{mg} / \mathrm{dl}, 151.10$ $\mathrm{mg} / \mathrm{dl}, 197.50 \mathrm{mg} / \mathrm{dl}, 210.00 \mathrm{mg} / \mathrm{dl}$ respectively, whereas corresponding controls were $103.81 \mathrm{mg} / \mathrm{dl}, 106.00 \mathrm{mg} / \mathrm{dl}$, $105.30 \mathrm{mg} / \mathrm{dl}, 125.00 \mathrm{mg} / \mathrm{dl}, 120.75 \mathrm{mg} / \mathrm{dl}$ respectively. The results clearly indicated that in case of 31-40, 41-50 and above 50 years age groups Vitiligo patients, the random blood sugar level elevated significantly as compared to control, which diagrammatic represent in Fig. 1.

The serum bilirubin level of the different age group of patients and corresponding to their controls are mentioned in Table II and diagrammatically represent in Fig. 2. The Table II shown that the average serum bilirubin level of the below 10 years, 11-20 years, 21-30 years, 31-40 years $41-50$

Table I: Random Blood Sugar level (mg/dl) of the patients among different age groups

\begin{tabular}{lcccccccccccc}
\hline Age group & \multicolumn{2}{c}{ Below 10} & \multicolumn{2}{c}{$11-20$} & \multicolumn{2}{c}{$21-30$} & \multicolumn{2}{c}{$31-40$} & \multicolumn{2}{c}{$41-50$} & \multicolumn{2}{c}{ Above 50 } \\
\hline & $\mathrm{A}^{1}$ & $\mathrm{~B}^{2}$ & $\mathrm{~A}^{1}$ & $\mathrm{~B}^{2}$ & $\mathrm{~A}^{1}$ & $\mathrm{~B}^{2}$ & $\mathrm{~A}^{1}$ & $\mathrm{~B}^{2}$ & $\mathrm{~A}^{1}$ & $\mathrm{~B}^{2}$ & $\mathrm{~A}^{1}$ & $\mathrm{~B}^{2}$ \\
n & 10 & 10 & 55 & 55 & 30 & 30 & 20 & 20 & 6 & 6 & 4 & 4 \\
Average & 77.500 & 78.00 & 101.38 & 103.81 & 126.56 & 106.00 & 151.10 & 105.30 & 197.50 & 125.00 & 210.00 & 120.75 \\
SD & 18.283 & 15.861 & 35.449 & 30.793 & 46.702 & 32.426 & 37.01 & 30.87 & 32.83 & 23.02 & 35.59 & 27.73 \\
t-value & \multicolumn{2}{c}{0.07} & \multicolumn{2}{c}{0.38} & \multicolumn{2}{c}{1.98} & $3.01(\mathrm{p}<0.01)$ & $4.43(\mathrm{p}<0.01)$ & $3.96(\mathrm{p}<0.01)$ \\
\hline
\end{tabular}

$\mathrm{A}^{1}$ - Patients

$\mathrm{B}^{2}$-Controls

$\mathrm{n}$-Number of patients and controls

The average random blood sugar level of the 11-20 years, 21-30 years, 31-40 years, $41-50$ years and above 50 years

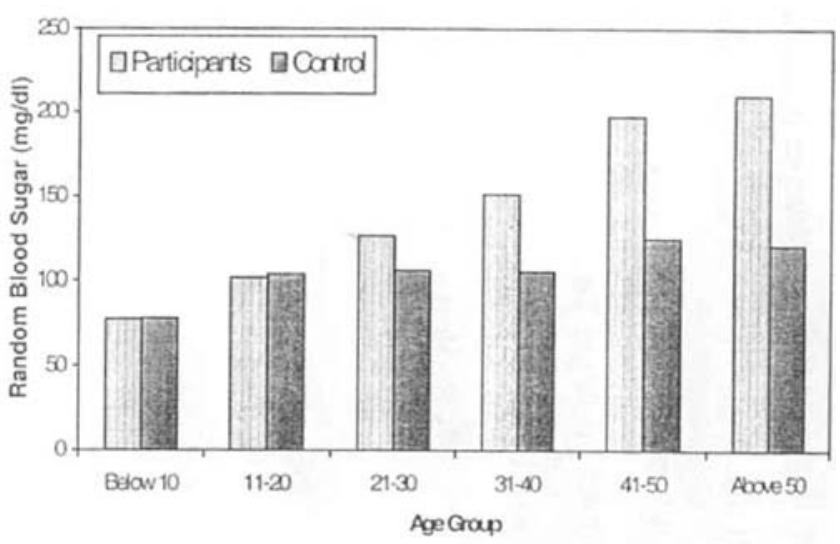

Fig. 1: Random blood sugar level of the Vitiligo patients and controls. The longest bar indicates the blood sugar level was highest above 50 years agegroup(around $200 \mathrm{mg} / \mathrm{dl}$ ) and the shortest bar indicates the lowest blood sugar level was observed around age group 11-20 or below 10 years (around $80 \mathrm{mg} / \mathrm{dl}$ ). The black bar indicates the controls and the participants with Vitiligo. years and above 50 years age group patients were 1.51 $\mathrm{mg} / \mathrm{dl}, \quad 0.67 \mathrm{mg} / \mathrm{dl}, 0.63 \mathrm{mg} / \mathrm{dl}, 0.87 \mathrm{mg} / \mathrm{dl}, 0.92 \mathrm{mg} / \mathrm{dl}$ respectively and the corresponding controls were 0.67 $\mathrm{mg} / \mathrm{dl}, 0.56 \mathrm{mg} / \mathrm{dl}, 0.65 \mathrm{mg} / \mathrm{dl}, 0.62 \mathrm{mg} / \mathrm{dl}, 0.81 \mathrm{mg} / \mathrm{dl}, 0.82$ $\mathrm{mg} / \mathrm{dl}$ respectively. In this analyses only age group 11-20 years, the $t$ value was $1.988(\mathrm{P}<0.05)$ significant, for bilirubin level in patients and control individuals.

The estimated results of the serum urea in Vitiligo patients and corresponding controls of the different age group are shown in Table IIIa and Fig. 3a.The Table IIIa reveal that the average serum urea level of the age groups below 10 years, 11-20 years, 21-30 years, 31-40 years, $41-50$ years and in above 50 years age groups patients were $19.5 \mathrm{mg} / \mathrm{dl}, 27.10$ $\mathrm{mg} / \mathrm{dl}, 27.00 \mathrm{mg} / \mathrm{dl}, 30.95 \mathrm{mg} / \mathrm{dl}, 31.83 \mathrm{mg} / \mathrm{dl}, 36.50 \mathrm{mg} / \mathrm{dl}$ respectively and corresponding controls were $18.80 \mathrm{mg} / \mathrm{dl}$, $23.90 \mathrm{mg} / \mathrm{dl}, 22.80 \mathrm{mg} / \mathrm{dl}, 24.10 \mathrm{mg} / \mathrm{dl}, 27.33 \mathrm{mg} / \mathrm{dl}, 23.25$ $\mathrm{mg} / \mathrm{dl}$ respectively. No significant changes of serum urea level were observed of the Vitiligo patients as compared with controls (Fig. 3a). 
Table II: Serum Bilirubin level (mg/dl) of the patients among different age groups

\begin{tabular}{|lccccccccccccc}
\hline Age group & \multicolumn{3}{c}{ Below 10 } & \multicolumn{2}{c}{$11-20$} & \multicolumn{2}{c}{$21-30$} & \multicolumn{2}{c}{$31-40$} & \multicolumn{2}{c}{$41-50$} & \multicolumn{2}{c}{ Above 50 } \\
\hline & $\mathrm{A}^{1}$ & $\mathrm{~B}^{2}$ & $\mathrm{~A}^{1}$ & $\mathrm{~B}^{2}$ & $\mathrm{~A}^{1}$ & $\mathrm{~B}^{2}$ & $\mathrm{~A}^{1}$ & $\mathrm{~B}^{2}$ & $\mathrm{~A}^{1}$ & $\mathrm{~B}^{2}$ & $\mathrm{~A}^{1}$ & $\mathrm{~B}^{2}$ \\
n & 10 & 10 & 55 & 55 & 30 & 30 & 20 & 20 & 6 & 6 & 4 & 4 \\
Average & 1.519 & 0.672 & 0.67 & 0.56 & 0.63 & 0.65 & 0.62 & 0.62 & 0.87 & 0.81 & 0.92 & 0.82 \\
SD & 1.247 & 0.291 & 0.37 & 0.22 & 0.38 & 0.30 & 0.31 & 0.30 & 0.15 & 0.14 & 0.18 & 0.13 \\
t-value & \multicolumn{2}{c}{2.09} & & $1.988(\mathrm{p}<0.05)$ & \multicolumn{2}{c}{0.193} & 0.016 & 0.760 & 0.923
\end{tabular}

$\mathrm{A}^{1}$ - Patients

$\mathrm{B}^{2}$-Controls

n-Number of patients and controls

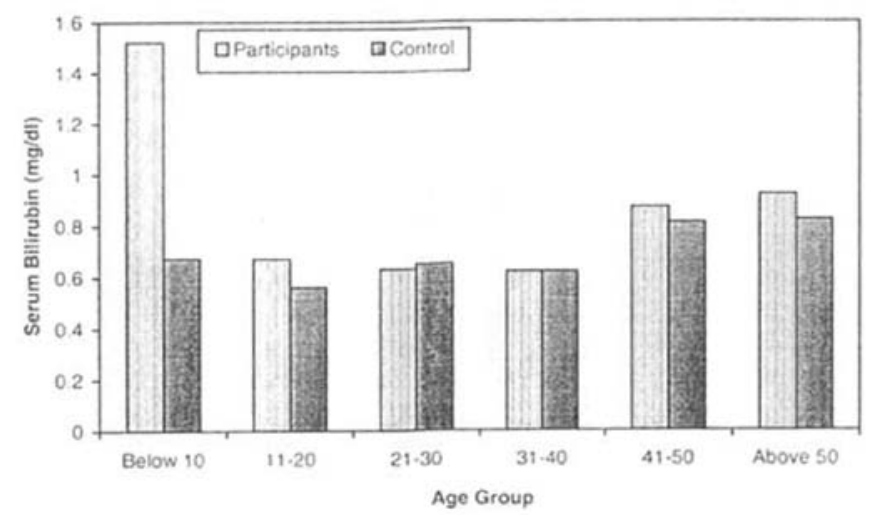

Fig. 2: Serum bilirubin level of the Vitiligo patients and controls. The longest bar indicates the bilirubin level was highest below 10 years age group as compared to the controls. No significant change was observed in others age group. The black bar indicates the controls and the white bar indicates the participant Vitiligo patients

To observed the serum creatinine in Vitiligo patients. In this study, the estimation of serum creatinine level performed among the different age group of patients and corresponding to controls. The Table IIIb mentioned that the average serum creratinine level of the below 10 years, 11-20 years, 21-30 years, 31-40 years, 41-50 years and above 50 years age group patients were $0.67 \mathrm{mg} / \mathrm{dl}, 0.79 \mathrm{mg} / \mathrm{dl}, 0.78 \mathrm{mg} / \mathrm{dl}, 0.75$ $\mathrm{mg} / \mathrm{dl}, 0.93 \mathrm{mg} / \mathrm{dl}, 0.97 \mathrm{mg} / \mathrm{dl}$ respectively and corresponding controls were $0.63 \mathrm{mg} / \mathrm{dl}, 0.72 \mathrm{mg} / \mathrm{dl}, 0.77 \mathrm{mg} / \mathrm{dl}, 0.74$ $\mathrm{mg} / \mathrm{dl}, 0.81 \mathrm{mg} / \mathrm{dl}$ and $0.78 \mathrm{mg} / \mathrm{dl}$, respectively. As per literature, the normal value for the serum creatinine in human is $0.6 \mathrm{mg} / \mathrm{dl}$ to $1.2 \mathrm{mg} / \mathrm{dl}$. This results suggested that serum creratinine level of the Vitiligo patients among different age group was not significantly elevated (shown in Figure 3b).

In this study, we estimated the serum total protein of the Vitiligo patients among different age groups. The normal serum total protein level is $6.6 \mathrm{~g} / \mathrm{dl}$ to $8.7 \mathrm{~g} / \mathrm{dl}$ for human, as per literature. The calculated mean total protein levels in the patients and corresponding control subjects among the different age group are given in Table IIIc and diagrammatically shown in Fig. 3c. The average serum total protein level for the below 10 years, $11-20$ years, $21-30$ years, $31-40$ years , 41-50 years and above 50 years age group were $5.31 \mathrm{~g} / \mathrm{dl}$, $6.50 \mathrm{~g} / \mathrm{dl}, 7.00 \mathrm{~g} / \mathrm{dl}, 7.00 \mathrm{~g} / \mathrm{dl}, 6.90 \mathrm{~g} / \mathrm{dl}, 7.40 \mathrm{~g} / \mathrm{dl}$ respectively and corresponding controls were $5.95 \mathrm{~g} / \mathrm{dl}, 6.92 \mathrm{~g} / \mathrm{dl} 6.90$ $\mathrm{g} / \mathrm{dl}, 7.46 \mathrm{~g} / \mathrm{dl}, 6.88 \mathrm{~g} / \mathrm{dl}$ and $7.27 \mathrm{~g} / \mathrm{dl}$ respectively. In this study, serum total protein level was significantly low at the age group below 10 years and 11-20 years. The t-test performed that $\mathrm{p}<0.05$ which found significant.

For the estimation of serum ALT/SGPT (U/L) of the Vitiligo patients among different age groups we performed the exper

Table IIIa: Serum Urea level (mg/dl) of the patients among different age group and corresponding controls

\begin{tabular}{lcccccccccccc}
\hline Age group & \multicolumn{2}{c}{ Below 10} & \multicolumn{2}{c}{$11-20$} & \multicolumn{2}{c}{$21-30$} & \multicolumn{2}{c}{$31-40$} & \multicolumn{2}{c}{$41-50$} & \multicolumn{2}{c}{ Above 50 } \\
\hline & $\mathrm{A}^{1}$ & $\mathrm{~B}^{2}$ & $\mathrm{~A}^{1}$ & $\mathrm{~B}^{2}$ & $\mathrm{~A}^{1}$ & $\mathrm{~B}^{2}$ & $\mathrm{~A}^{1}$ & $\mathrm{~B}^{2}$ & $\mathrm{~A}^{1}$ & $\mathrm{~B}^{2}$ & $\mathrm{~A}^{1}$ & $\mathrm{~B}^{2}$ \\
n & 10 & 10 & 55 & 55 & 30 & 30 & 20 & 20 & 6 & 6 & 4 & 4 \\
Average & 19.500 & 18.800 & 27.109 & 23.909 & 27.000 & 22.800 & 30.950 & 24.100 & 31.833 & 27.333 & 36.500 & 23.250 \\
SD & 5.255 & 3.293 & 13.189 & 8.271 & 11.765 & 8.790 & 14.274 & 13.266 & 6.940 & 12.32 & 35.000 & 6.702 \\
t-value & \multicolumn{2}{c}{0.36} & \multicolumn{2}{c}{1.52} & \multicolumn{2}{c}{1.57} & & 1.57 & 0.78 & $3.17(\mathrm{p}<0.05)$ \\
\hline
\end{tabular}

$\mathrm{A}^{1}$ - Patients

$\mathrm{B}^{2}$-Controls

n-Number of patients and controls 


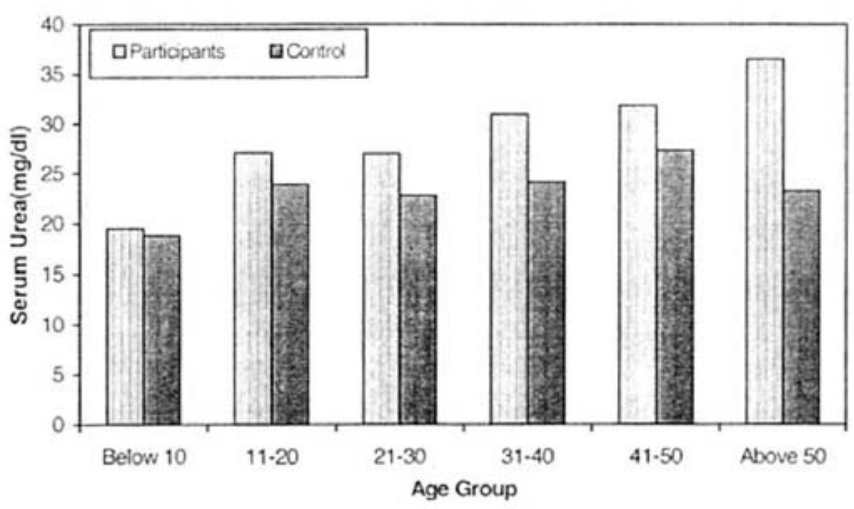

Fig. 3a: Serum urea level of the Vitiligo patients and controls. The longest bar indicates the urea level was highest above 50 years age group (around $45 \mathrm{mg} / \mathrm{dl}$ ) and the shortest bar indicates the lowest urea level was observed around age group 11-20 or below 10 years (around $18 \mathrm{mg} / \mathrm{dl}$ ). The black bar indicates the controls and the participants with Vitiligo. iment. The obtaining results are mentioned in Table IVa. The Table IVa reveal that the average serum ALT level in the below 10 years, 11-20 years, 21-30 years, 31-40 years, $41-50$ years and above 50 years age groups patients were 20.50 $\mathrm{U} / \mathrm{L}, 31.47 \mathrm{U} / \mathrm{L}, 28.93 \mathrm{U} / \mathrm{L}, 30.85 \mathrm{U} / \mathrm{L} 44.33 \mathrm{U} / \mathrm{L}, 39.40 \mathrm{U} / \mathrm{L}$ respectively and controls were $19.10 \mathrm{U} / \mathrm{L}, 27.60 \mathrm{U} / \mathrm{L}, 27.57$ $\mathrm{U} / \mathrm{L}, 30.30 \mathrm{U} / \mathrm{L}, 30.67 \mathrm{U} / \mathrm{L}, 34.25 \mathrm{U} / \mathrm{L}$ respectively. There was no significant change of the serum Alanine aminotransferase (ALT) in the patients from the corresponding controls (shown in Fig. 4a).

To determine the level of serum alkaline phosphatase for Vtiligo patients, in this study, we estimate the serum Alkaline phosphatase (U/L) among different age group of patients and control individuals (Table IVb). Table IVb exhibited that the average serum ALP level in below 10 years, 11-20 years, 21-30 years, 31-40 years, 41-50 years and above 50 years age groups patients were $160.10 \mathrm{U} / \mathrm{L}$, 75.62 U/L, 83.00 U/L, 85.85 U/L, $105.83 \mathrm{U} / \mathrm{L}, 124.50 \mathrm{U} / \mathrm{L}$

Table IIIb: Serum Creatinine level (mg/dl) of the patients among different age groups

\begin{tabular}{lccccccccccccc}
\hline Age group & \multicolumn{2}{c}{ Below 10 } & \multicolumn{2}{c}{$11-20$} & \multicolumn{2}{c}{$21-30$} & \multicolumn{2}{c}{$31-40$} & \multicolumn{2}{c}{$41-50$} & \multicolumn{2}{c}{ Above 50 } \\
\hline & $\mathrm{A}^{1}$ & $\mathrm{~B}^{2}$ & $\mathrm{~A}^{1}$ & $\mathrm{~B}^{2}$ & $\mathrm{~A}^{1}$ & $\mathrm{~B}^{2}$ & $\mathrm{~A}^{1}$ & $\mathrm{~B}^{2}$ & $\mathrm{~A}^{1}$ & $\mathrm{~B}^{2}$ & $\mathrm{~A}^{1}$ & $\mathrm{~B}^{2}$ \\
$\mathrm{n}$ & 10 & 10 & 55 & 55 & 30 & 30 & 20 & 20 & 6 & 6 & 4 & 4 \\
Average & 0.673 & 0.634 & 0.790 & 0.724 & 0.789 & 0.773 & 0.750 & 0.749 & 0.932 & 0.810 & 0.975 & 0.783 \\
SD & 0.093 & 0.102 & 0.205 & 0.188 & 0.149 & 0.159 & 0.155 & 0.168 & 0.231 & 0.199 & 0.208 & 0.137 \\
t-value & \multicolumn{3}{c}{0.89} & \multicolumn{2}{c}{1.76} & \multicolumn{2}{c}{0.39} & 0.03 & 0.98 & 1.55 \\
\hline
\end{tabular}

$\mathrm{A}^{1}$ - Patients, $\mathrm{B}^{2}$-Controls, $\mathrm{n}-$ Number of patients and controls

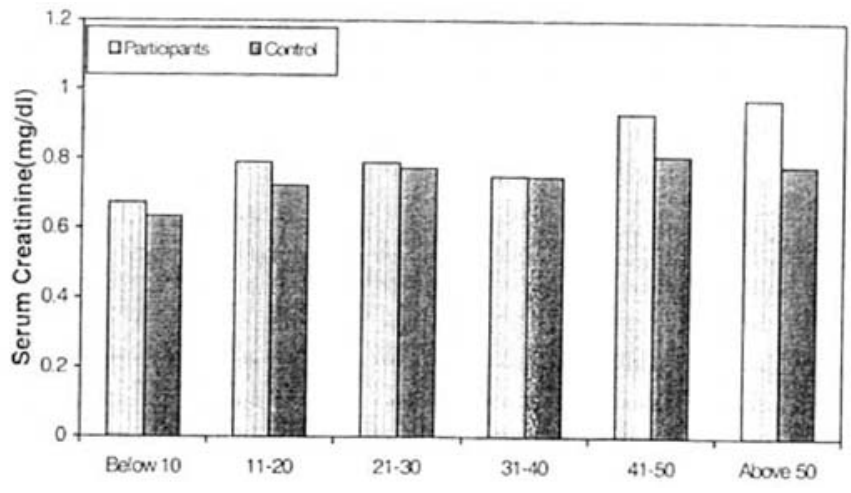

Fig. 3b: Serum creatinine level of the Vitiligo patients and controls. The longest bar indicates the highest serum creatinine level were observed in 41-50 years age group and above 50 years age group (around $1.00 \mathrm{mg} / \mathrm{dl}$ ) and the shortest bar indicates the lowest level of serum creatinine in around age group 11-20 or below 10 years (around 18mg/dl). The black bar indicates the controls and the white bar indicates the participants with Vitiligo respectively and for the controls were $150.20 \mathrm{U} / \mathrm{L}, 73.45$ $\mathrm{U} / \mathrm{L}, 82.70 \mathrm{U} / \mathrm{L}, 81.35 \mathrm{U} / \mathrm{L}, 96.17 \mathrm{U} / \mathrm{L}, 107.50 \mathrm{U} / \mathrm{L}$ respectively . As per literature, the normal range of serum ALP is $100 \mathrm{U} / \mathrm{L}$ to $290 \mathrm{U} / \mathrm{L}$. As compared to normal range, the Fig. $4 \mathrm{~b}$ represent that there was no significant elevation of ALP level in serum of the patients.

In this study, we also performed the estimation of serum Asparate aminotransferase (AST) level of the patients among different age groups. The estimated AST level of the different age group patients and control individuals are shown in the Table IVc and Fig. 4c. The Table IVc represent that the average serum AST value of below10 years, 11-20 years, 21-30 years, 31-40 years, $41-50$ years and above 50 years age groups patients were $11.25 \mathrm{U} / \mathrm{L}, 15.78 \mathrm{U} / \mathrm{L}, 17.17$ $\mathrm{U} / \mathrm{L}, 23.55 \mathrm{U} / \mathrm{L}, 25.00 \mathrm{U} / \mathrm{L}, 34.50 \mathrm{U} / \mathrm{L}$ respectively and for the controls were $10.70 \mathrm{U} / \mathrm{L}, 15.05 \mathrm{U} / \mathrm{L}, 17.93 \mathrm{U} / \mathrm{L}$, $20.85 \mathrm{U} / \mathrm{L}, 25.83 \mathrm{U} / \mathrm{L}, 28.25 \mathrm{U} / \mathrm{L}$ respectively. Normal range of serum AST is up to $40 \mathrm{U} / \mathrm{L}$ as per literature The 
Table IIIc: Serum Total Protein level(mg/dl) of the patients among different age groups

\begin{tabular}{lccccccccccccc}
\hline Age group & \multicolumn{2}{c}{ Below 10} & \multicolumn{2}{c}{$11-20$} & \multicolumn{2}{c}{$21-30$} & \multicolumn{2}{c}{$31-40$} & \multicolumn{2}{c}{$41-50$} & \multicolumn{2}{c}{ Above 50 } \\
& $\mathrm{A}^{1}$ & $\mathrm{~B}^{2}$ & $\mathrm{~A}^{1}$ & $\mathrm{~B}^{2}$ & $\mathrm{~A}^{1}$ & $\mathrm{~B}^{2}$ & $\mathrm{~A}^{1}$ & $\mathrm{~B}^{2}$ & $\mathrm{~A}^{1}$ & $\mathrm{~B}^{2}$ & $\mathrm{~A}^{1}$ & $\mathrm{~B}^{2}$ \\
$\mathrm{n}$ & 10 & 10 & 55 & 55 & 30 & 30 & 20 & 20 & 6 & 6 & 4 & 4 \\
Average & 5.317 & 5.957 & 6.501 & 6.927 & 7.005 & 6.900 & 7.003 & 7.460 & 6.908 & 6.883 & 7.405 & 7.275 \\
$\mathrm{SD}$ & 0.554 & 0.770 & 0.838 & 0.957 & 1.128 & 0.868 & 0.822 & 0.649 & 1.208 & 1.182 & 0.555 & 0.838 \\
$\mathrm{t}$-value & $2.13(\mathrm{p}<0.05)$ & $2.48(\mathrm{p}<0.05)$ & \multicolumn{2}{c}{0.40} & \multicolumn{2}{c}{1.95} & & 0.04 & 0.26 \\
\hline
\end{tabular}

$\mathrm{A}^{1}$ - Patients, $\mathrm{B}^{2}$-Controls, $\mathrm{n}$-Number of patients and controls

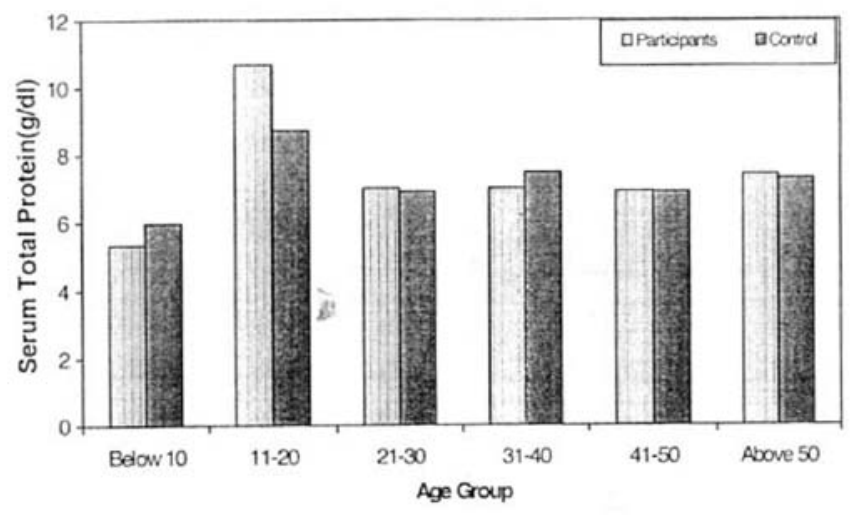

Fig. 3c: Serum total protein level in Vitiligo patients and controls. The longest bar indicates the highest serum total protein level was observed in the 1120 years age group both the controls and the participants with Vitiligo. No significant change was observed in others age group in both the controls and the participants with Vitiligo. The black bar indicates the control and the white bar indicates the participant with Vitiligo. group such as below 10 years, 11-20 years, 21-30 years, 3140 years, $41-50$ years and above 50 years age group patients were $118.70 \mathrm{mg} / \mathrm{dl}, 137.80 \mathrm{mg} / \mathrm{dl}, 152.17 \mathrm{mg} / \mathrm{dl}, 173.40$ $\mathrm{mg} / \mathrm{dl}, 167.50 \mathrm{mg} / \mathrm{dl}, 160.75 \mathrm{mg} / \mathrm{dl}$ respectively and corresponding controls were $121.00 \mathrm{mg} / \mathrm{dl}, 144.93 \mathrm{mg} / \mathrm{dl}, 150.57$ $\mathrm{mg} / \mathrm{dl}, 156.75 \mathrm{mg} / \mathrm{dl}, 167.00 \mathrm{mg} / \mathrm{dl}, 167.25 \mathrm{mg} / \mathrm{dl}$ respectively. Normal range of the serum total cholesterol level is $140 \mathrm{mg} / \mathrm{dl}$ to $250 \mathrm{mg} / \mathrm{dl}$, as per literature. In this observation, only 31-40 years age group serum cholesterol level was significantly different in Vitiligo patients from healthy controls. Fig. 5a represents the diagrammatic representation of the elevation of the serum cholesterol level in the 31-40 years age group compared to others.

Serum Triglyceride $(\mathrm{mg} / \mathrm{dl})$ level of the patients among the different age groups were also determined in this study. Table $5 \mathrm{~b}$ showed that the average serum TG level of the different age groups like below 10 years, 11-20 years, 21-30 years, 31-40 years, 41-50 years and above 50 years age group patients were $72.70 \mathrm{mg} / \mathrm{dl}, 90.27 \mathrm{mg} / \mathrm{dl}, 113.13$

Table IVa: Serum Alanine Aminotransferase level $(\mu / 1)$ of the patients among different age groups

\begin{tabular}{lcccccccccccc}
\hline Age group & \multicolumn{2}{c}{ Below 10} & \multicolumn{2}{c}{$11-20$} & \multicolumn{2}{c}{$21-30$} & \multicolumn{2}{c}{$31-40$} & \multicolumn{2}{c}{$41-50$} & \multicolumn{2}{c}{ Above 50 } \\
\hline & $\mathrm{A}^{1}$ & $\mathrm{~B}^{2}$ & $\mathrm{~A}^{1}$ & $\mathrm{~B}^{2}$ & $\mathrm{~A}^{1}$ & $\mathrm{~B}^{2}$ & $\mathrm{~A}^{1}$ & $\mathrm{~B}^{2}$ & $\mathrm{~A}^{1}$ & $\mathrm{~B}^{2}$ & $\mathrm{~A}^{1}$ & $\mathrm{~B}^{2}$ \\
$\mathrm{n}$ & 10 & 10 & 55 & 55 & 30 & 30 & 20 & 20 & 6 & 6 & 4 & 4 \\
Average & 20.50 & 19.10 & 31.47 & 27.60 & 28.93 & 27.57 & 30.85 & 30.30 & 44.33 & 30.67 & 39.50 & 34.25 \\
SD & 11.63 & 8.91 & 27.51 & 18.12 & 21.43 & 16.45 & 22.27 & 15.91 & 21.36 & 7.97 & 8.43 & 7.41 \\
t-value & \multicolumn{2}{c}{0.302} & \multicolumn{2}{c}{0.872} & & 0.277 & & 0.090 & & 1.468 & 0.936 \\
\hline
\end{tabular}

$\mathrm{A}^{1}$ - Patients, $\mathrm{B}^{2}$-Controls, $\mathrm{n}$-Number of patients and controls

Fig. 4c represent that there was no significant elevated level of serum AST were observed in the patients of Vitiligo as compared to the control individuals.

In this present study, Table Va and Fig. 5a shown the different estimated cholesterol level of the patients and controls in different age group. It was estimated from the Table Va that the average serum cholesterol level of the different age $\mathrm{mg} / \mathrm{dl}, 149.95 \mathrm{mg} / \mathrm{dl}, 150.00 \mathrm{mg} / \mathrm{dl}, 138.75 \mathrm{mg} / \mathrm{dl}$ respectively and corresponding controls were $78.10 \mathrm{mg} / \mathrm{dl}, 94.41$ $\mathrm{mg} / \mathrm{dl}, 101.80 \mathrm{mg} / \mathrm{dl}, 116.35 \mathrm{mg} / \mathrm{dl}, 127.16 \mathrm{mg} / \mathrm{dl}, 120.00$ $\mathrm{mg} / \mathrm{dl}$ respectively. As per literature, the normal range of serum triglyceride level is $60 \mathrm{mg} / \mathrm{dl}$ to $165 \mathrm{mg} / \mathrm{dl}$. From Fig. $4 \mathrm{~b}$, it appeared that there was no significant change of the patients in serum TG level in comparison to controls. 


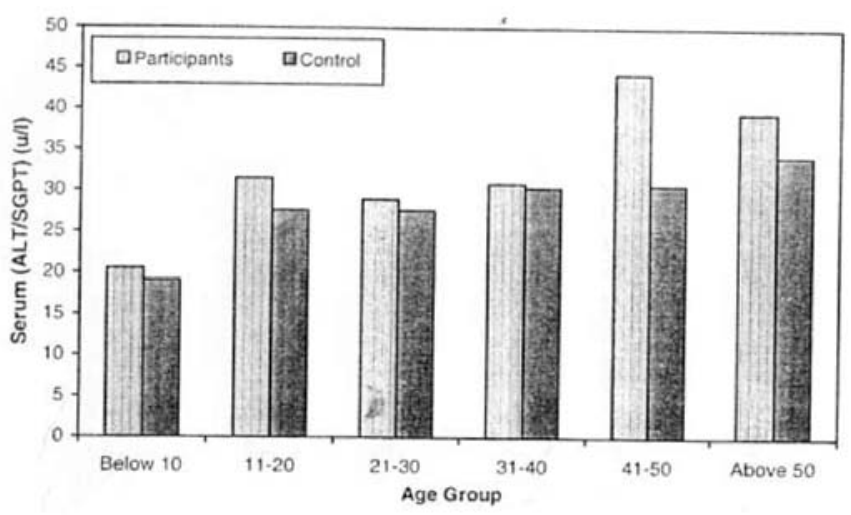

Fig. 4a: Alanine aminotransferase level of the Vitiligo patients and controls. The longest bar indicates the highest serum aminotransferase level were observed in 41-50 years age group and above 50 years age group (around $45 \mathrm{mg} / \mathrm{dl}$ ) and no significant change of the serum alanine aminotransferase level was observed in the other age group as compare to the controls. The black bar indicates the controls and the white bar indicates the participants with Vitiligo

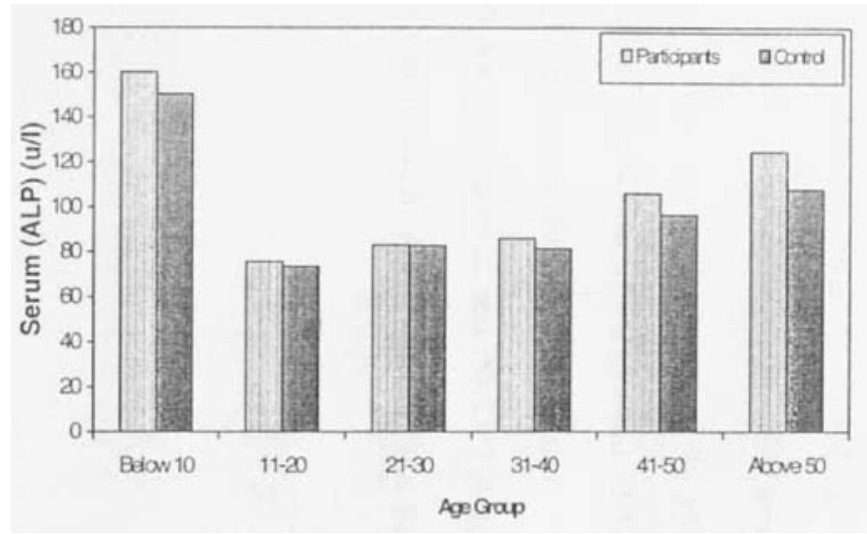

Fig. 4b: Alkaline phosphatase level of the patients and controls. The longest bar indicates the highest serum alkaline phosphatase level were observed in below 10 years age group and no significant change of the serum alkaline phosphatase level were observed in the other age groups as compare to the controls. The black bar indicates the controls and the white bar indicates the participants with Vitiligo

of the patients and controls. The average serum HDL level of the below 10 years, $11-20$ years, $21-30$ years, $31-40$ years, 41-50 years and above 50 years age groups were 47.60

Table IVb: Serum Alkaline Phosphatase $(\mu / \mathrm{l})$ of the patients among different age groups

\begin{tabular}{lcccccccccccc}
\hline Age group & \multicolumn{2}{c}{ Below 10} & \multicolumn{2}{c}{$11-20$} & \multicolumn{2}{c}{$21-30$} & \multicolumn{2}{c}{$31-40$} & \multicolumn{2}{c}{$41-50$} & \multicolumn{2}{c}{ Above 50 } \\
\hline & $\mathrm{A}^{1}$ & $\mathrm{~B}^{2}$ & $\mathrm{~A}^{1}$ & $\mathrm{~B}^{2}$ & $\mathrm{~A}^{1}$ & $\mathrm{~B}^{2}$ & $\mathrm{~A}^{1}$ & $\mathrm{~B}^{2}$ & $\mathrm{~A}^{1}$ & $\mathrm{~B}^{2}$ & $\mathrm{~A}^{1}$ & $\mathrm{~B}^{2}$ \\
$\mathrm{n}$ & 10 & 10 & 55 & 55 & 30 & 30 & 20 & 20 & 6 & 6 & 4 & 4 \\
Average & 160.10 & 150.20 & 75.62 & 73.45 & 83.00 & 82.70 & 85.85 & 81.35 & 105.83 & 96.17 & 124.50 & 107.50 \\
SD & 53.68 & 33.78 & 25.97 & 26.43 & 36.71 & 23.01 & 23.99 & 23.45 & 10.38 & 15.43 & 34.41 & 19.36 \\
t-value & \multicolumn{2}{c}{0.494} & \multicolumn{2}{c}{0.433} & \multicolumn{2}{c}{0.036} & 0.600 & 1.273 & 0.861 \\
\hline
\end{tabular}

$\mathrm{A}^{1}$ - Patients, $\mathrm{B}^{2}$-Controls, $\mathrm{n}$-Number of patients and controls

In case of serum high-density lipoprotein (HDL), the normal range is $<35 \mathrm{mg} / \mathrm{dl}$, as per literature. Table Vc and Fig. $5 \mathrm{c}$ shown the different serum HDL level for different age group $\mathrm{mg} / \mathrm{dl}, 42.94 \mathrm{mg} / \mathrm{dl}, 40.46 \mathrm{mg} / \mathrm{dl}, 37.55 \mathrm{mg} / \mathrm{dl}, 38.00 \mathrm{mg} / \mathrm{dl}$, $35.75 \mathrm{mg} / \mathrm{dl}$ respectively and controls were $46.80 \mathrm{mg} / \mathrm{dl}$, $44.78 \mathrm{mg} / \mathrm{dl}, 42.36 \mathrm{mg} / \mathrm{dl}, 37.75 \mathrm{mg} / \mathrm{dl}, 37.66 \mathrm{mg} / \mathrm{dl}, 35.00$

Table IVc: Serum Asparate Aminotransferase $(\mu / \mathrm{l})$ of the patients among different age groups

\begin{tabular}{|c|c|c|c|c|c|c|c|c|c|c|c|c|}
\hline$\overline{\text { Age group }}$ & \multicolumn{2}{|c|}{ Below 10} & \multicolumn{2}{|c|}{$11-20$} & \multicolumn{2}{|c|}{$21-30$} & \multicolumn{2}{|c|}{$31-40$} & \multicolumn{2}{|c|}{$41-50$} & \multicolumn{2}{|c|}{ Above 50} \\
\hline & $\mathrm{A}^{1}$ & $\mathrm{~B}^{2}$ & $\mathrm{~A}^{1}$ & $\mathrm{~B}^{2}$ & $\mathrm{~A}^{1}$ & $\mathrm{~B}^{2}$ & $\mathrm{~A}^{1}$ & $\mathrm{~B}^{2}$ & $\mathrm{~A}^{1}$ & $\mathrm{~B}^{2}$ & $\mathrm{~A}^{1}$ & $\mathrm{~B}^{2}$ \\
\hline $\mathrm{n}$ & 10 & 10 & 55 & 55 & 30 & 30 & 20 & 20 & 6 & 6 & 4 & 4 \\
\hline Average & 11.25 & 10.70 & 15.78 & 15.05 & 17.17 & 17.93 & 23.55 & 20.85 & 25.00 & 25.83 & 34.50 & 28.25 \\
\hline SD & 3.77 & 2.11 & 6.96 & 4.70 & 7.44 & 5.50 & 8.79 & 7.59 & 16.83 & 8.91 & 11.70 & 9.25 \\
\hline $\mathrm{t}$-value & & 0.275 & & 0.643 & & & & & & & & \\
\hline
\end{tabular}

$\mathrm{A}^{1}$ - Patients

$\mathrm{B}^{2}$-Controls

n-Number of patients and controls 


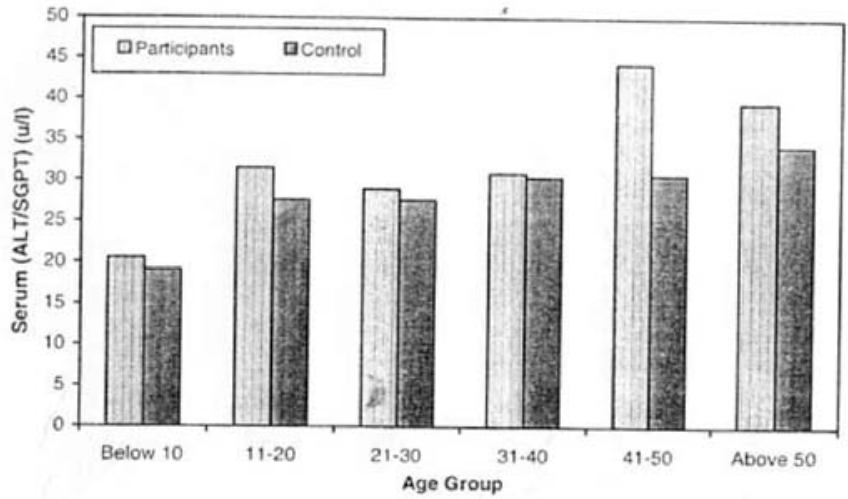

Fig. 4c: Asparate aminotransferase level of the Vitiligo patients and controls. The longest bar indicates the highest level of asparate aminotransferase level of the Vitiligo patients as compare to controls. No significant change of the serum asparate aminotransferase level were observed in the other age groups as compare to the controls. The black bar indicates the controls and the white bar indicates the participants with Vitiligo.

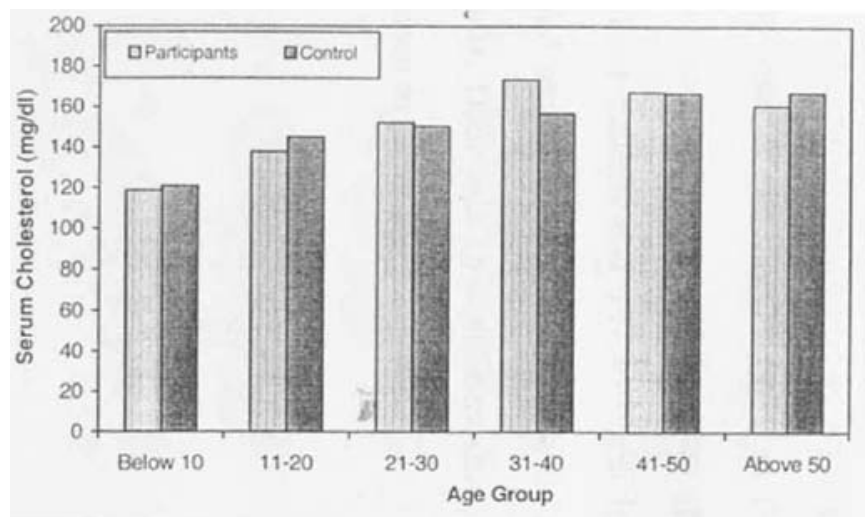

Fig. 5a: Serum cholesterol level of the Vitiligo patients and controls. The bar indicates the above 50 years age group showed average serum cholesterol level $160.75 \mathrm{mg} / \mathrm{dl}$ and $167.25 \mathrm{mg} / \mathrm{dl}$ in the patients and controls, respectively. The bar of 31-40 years age group serum cholesterol level indicates significantly different in Vitiligo patients from healthy controls.

Table Va: Serum Cholesterol level (mg/dl) of the patients among different age groups

\begin{tabular}{lcccccccccccc}
\hline Age group & \multicolumn{1}{c}{ Below 10} & \multicolumn{2}{c}{$11-20$} & \multicolumn{2}{c}{$21-30$} & \multicolumn{2}{c}{$31-40$} & \multicolumn{2}{c}{$41-50$} & \multicolumn{2}{c}{ Above 50 } \\
\hline & $\mathrm{A}^{1}$ & $\mathrm{~B}^{2}$ & $\mathrm{~A}^{1}$ & $\mathrm{~B}^{2}$ & $\mathrm{~A}^{1}$ & $\mathrm{~B}^{2}$ & $\mathrm{~A}^{1}$ & $\mathrm{~B}^{2}$ & $\mathrm{~A}^{1}$ & $\mathrm{~B}^{2}$ & $\mathrm{~A}^{1}$ & $\mathrm{~B}^{2}$ \\
$\mathrm{n}$ & 10 & 10 & 55 & 55 & 30 & 30 & 20 & 20 & 6 & 6 & 4 & 4 \\
Average & 118.70 & 121.00 & 137.80 & 144.93 & 152.17 & 150.57 & 173.40 & 156.75 & 167.50 & 167.00 & 160.75 & 167.25 \\
$\mathrm{SD}$ & 11.41 & 12.05 & 21.58 & 16.55 & 16.16 & 15.76 & 28.73 & 14.51 & 13.97 & 7.32 & 19.72 & 11.00 \\
t-value & \multicolumn{2}{c}{0.438} & \multicolumn{2}{c}{1.944} & 0.388 & $2.313(\mathrm{p}<0.05)$ & 0.078 & 0.576 \\
\hline
\end{tabular}

$\mathrm{A}^{1}$ - Patients, $\mathrm{B}^{2}$-Controls, n-Number of patients and controls

Table Vb: Serum Triglycerides level $(\mathrm{mg} / \mathrm{dl})$ of the patient among different age groups

\begin{tabular}{lcccccccccccc}
\hline Age group & \multicolumn{2}{c}{ Below 10} & \multicolumn{2}{c}{$11-20$} & \multicolumn{2}{c}{$21-30$} & \multicolumn{2}{c}{$31-40$} & \multicolumn{2}{c}{$41-50$} & \multicolumn{2}{c}{ Above 50 } \\
\hline & $\mathrm{A}^{1}$ & $\mathrm{~B}^{2}$ & $\mathrm{~A}^{1}$ & $\mathrm{~B}^{2}$ & $\mathrm{~A}^{1}$ & $\mathrm{~B}^{2}$ & $\mathrm{~A}^{1}$ & $\mathrm{~B}^{2}$ & $\mathrm{~A}^{1}$ & $\mathrm{~B}^{2}$ & $\mathrm{~A}^{1}$ & $\mathrm{~B}^{2}$ \\
$\mathrm{n}$ & 10 & 10 & 55 & 55 & 30 & 30 & 20 & 20 & 6 & 6 & 4 & 4 \\
Average & 72.700 & 78.100 & 90.27 & 94.418 & 113.133 & 101.800 & 145.950 & 116.350 & 150.000 & 127.167 & 138.750 & 120.000 \\
SD & 17.770 & 10.949 & 30.528 & 30.332 & 34.571 & 33.511 & 51.038 & 35.739 & 41.473 & 34.988 & 47.148 & 63.377 \\
$\mathrm{t}$-value & \multicolumn{2}{c}{0.82} & \multicolumn{2}{c}{0.71} & \multicolumn{2}{c}{1.29} & $2.12(\mathrm{p}<0.05)$ & 1.03 & & 0.47 \\
\hline
\end{tabular}

$\mathrm{A}^{1}$ - Patients, $\mathrm{B}^{2}$-Controls, n-Number of patients and controls

$\mathrm{mg} / \mathrm{dl}$ respectively. There was no significant change observed in the serum HDL level of the patients as compared to control individuals (shown in Fig. 5c).

The uric acid level in different age group of patients and control subjects are shown in Table $5 \mathrm{~d}$. The average serum uric acid level of the below 10 years, 11-20 years, 21-30 years, $31-40$ years, $41-50$ years and above 50 years age groups were $3.88 \mathrm{mg} / \mathrm{dl}, 4.75 \mathrm{mg} / \mathrm{dl}, 4.73 \mathrm{mg} / \mathrm{dl}, 5.54 \mathrm{mg} / \mathrm{dl}, 5.80$ $\mathrm{mg} / \mathrm{dl}, 5.88 \mathrm{mg} / \mathrm{dl}$ respectively for the patients and for the controls were $3.71 \mathrm{mg} / \mathrm{dl}, 4.28 \mathrm{mg} / \mathrm{dl}, 4.31 \mathrm{mg} / \mathrm{dl}, 4.77$ 


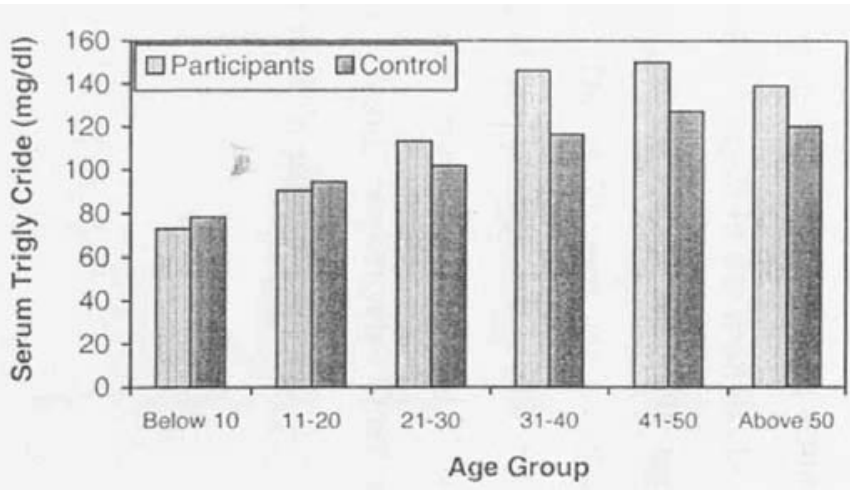

Fig. 5b: Serum triglycerides level of the Vitiligo patients and controls. The longest bar indicates the highest serum triglycerides level in 31-40 years age group and 41-50 year age group (around $145 \mathrm{mg} / \mathrm{dl}$ ) but no significant change of the serum triglycerides level were observed in the other age groups as compare to the controls. The black bar indicates the controls and the white bar indicates the participants with Vitiligo

\section{Discussion}

Vitiligo is a skin disorder characterizes by patchy areas of depigmentation due to the destruction of melanocytes in the epidermis. Although the etiology of the Vitiligo is unclear, both cellular and hormonal immune phenomena are considered to play a part in the pathogenesis of the disease.

The pathogenic mechanism in the Vitiligo an acquired depigmentory disorder that affects $0.5-5 \%$ of the world population, have not been completely clarified, although important clue have been found in recent years several reports have suggested a specific melanocytes defect, because melanocytes in the depigmented area can be absent or functionally inactive and in normally appearing skin present morphologic and biologic alternations and lower expression of the c-kit membrane receptors (Ortonne et al. 1993). In this biochemical study, 125 patients were studied simultaneously. This study reflected some disease condition and their pathogenesis.

Table Vc: Serum High Density Lipoprotein ( HDL) level (mg/dl) of the patients among different age groups

\begin{tabular}{lcccccccccccc}
\hline Age group & \multicolumn{2}{c}{ Below 10} & \multicolumn{2}{c}{$11-20$} & \multicolumn{2}{c}{$21-30$} & \multicolumn{2}{c}{$31-40$} & \multicolumn{2}{c}{$41-50$} & \multicolumn{2}{c}{ Above 50 } \\
\hline & $\mathrm{A}^{1}$ & $\mathrm{~B}^{2}$ & $\mathrm{~A}^{1}$ & $\mathrm{~B}^{2}$ & $\mathrm{~A}^{1}$ & $\mathrm{~B}^{2}$ & $\mathrm{~A}^{1}$ & $\mathrm{~B}^{2}$ & $\mathrm{~A}^{1}$ & $\mathrm{~B}^{2}$ & $\mathrm{~A}^{1}$ & $\mathrm{~B}^{2}$ \\
$\mathrm{n}$ & 10 & 10 & 55 & 55 & 30 & 30 & 20 & 20 & 6 & 6 & 4 & 4 \\
Average & 47.600 & 46.800 & 42.945 & 44.782 & 40.467 & 42.367 & 37.550 & 37.750 & 38.000 & 37.667 & 35.760 & 35.000 \\
SD & 7.734 & 7.300 & 7.266 & 6.599 & 4.249 & 6.830 & 7.052 & 7.070 & 7.694 & 7.090 & 2.872 & 6.000 \\
t-value & \multicolumn{2}{c}{0.24} & & \multicolumn{2}{c}{1.39} & \multicolumn{2}{c}{1.29} & 0.09 & 0.08 & 0.23 \\
\hline
\end{tabular}

$\mathrm{A}^{1}$ - Patients, $\mathrm{B}^{2}$-Controls, n-Number of patients and controls

Table Vd. Serum Uric acid level (mg/dl) of the patient among different age groups

\begin{tabular}{|c|c|c|c|c|c|c|c|c|c|c|c|c|}
\hline \multirow[t]{2}{*}{$\overline{\text { Age group }}$} & \multicolumn{2}{|c|}{ Below 10} & \multicolumn{2}{|c|}{$11-20$} & \multicolumn{2}{|c|}{$21-30$} & \multicolumn{2}{|c|}{$31-40$} & \multicolumn{2}{|c|}{$41-50$} & \multicolumn{2}{|c|}{ Above 50} \\
\hline & $\mathrm{A}^{1}$ & $\mathrm{~B}^{2}$ & $\mathrm{~A}^{1}$ & $\mathrm{~B}^{2}$ & $\mathrm{~A}^{1}$ & $\mathrm{~B}^{2}$ & $\mathrm{~A}^{1}$ & $\mathrm{~B}^{2}$ & $\mathrm{~A}^{1}$ & $\mathrm{~B}^{2}$ & $\mathrm{~A}^{1}$ & $\mathrm{~B}^{2}$ \\
\hline $\mathrm{n}$ & 10 & 10 & 55 & 55 & 30 & 30 & 20 & 20 & 6 & 6 & 4 & 4 \\
\hline Average & 3.885 & 3.710 & 4.758 & 4.288 & 4.736 & 4.311 & 5.542 & 4.773 & 5.80 & 54.718 & 5.883 & 5.020 \\
\hline SD & 0.831 & 0.718 & 1.084 & 0.790 & 1.014 & 0.645 & 0.770 & 0.640 & 0.598 & 0.781 & 1.058 & 0.174 \\
\hline t-value & \multicolumn{2}{|c|}{0.50} & \multicolumn{2}{|c|}{$2.60(\mathrm{p}<0.05)$} & \multicolumn{2}{|c|}{1.94} & \multicolumn{2}{|c|}{$3.44(\mathrm{p}<0.05)$} & $2.71(\mathrm{p}<$ & $0.05) 1.61$ & \multicolumn{2}{|c|}{0.23} \\
\hline
\end{tabular}

$\mathrm{A}^{1}$ - Patients, $\mathrm{B}^{2}$-Controls, $\mathrm{n}$-Number of patients and controls

$\mathrm{mg} / \mathrm{dl}, 4.71 \mathrm{mg} / \mathrm{dl}, 5.02 \mathrm{mg} / \mathrm{dl}$ respectively. But the normal range of the serum uric acid is $3.0 \mathrm{mg} / \mathrm{dl}$, as per literature. Therefore, the results indicated that serum uric acid level was elevated significantly in the age group 31-40 years of the patients comparison with normal healthy control individuals (Fig. 5d and Table 5d). The t-test showed that $\mathrm{p}<0.05$ which found significant.
Vitiligo may be an autoimmune disease, since it is associated with other autoimmune disease like diabetes melilitus, liver disease and pernicious anemia, hyper or hypothyroidism, addisons disease etc.

This investigation represent that there were $8 \%$ of Vitiligo patients had diabetes mellitus, $3.2 \%$ had renal disease 
(Lerner et al. 1959). Furthermore, it would be necessary to investigate hepatic, cardiac function of the Vitiligo patients compare to the normal healthy controls.

These biochemical analysis also reported that there were some blood parameters increasing to compare the Vitiligo patients with normal healthy controls. The increasing blood parameters were statistically significant with the age group. The most frequently associated disease is diabetes mellitus, pernicious anemia appear more commonly than reasonably expected. Incase of random blood sugar analysis of 125 patients, age group 31-40, 41-50 and above 50 significantly higher than the control group.

Dawber et al. 1970 found diabetes mellitus both juvenile and adult onset type occur in 1 to $7 \%$ of Vitiligo patients and conversely Vitiligo occurs in $4.8 \%$ of diabetes patients.

Serum bilirubin was one of the blood parameter that was analyzed among all patients and compared with the healthy persons. There were no significant changes observed in this study. This finding could be suggested that Vitiligo is not associated with jaundice.

Serum urea and creatinine were analyzed among 125 patients. However there were no significant changes observed in the all ages of the Vitiligo patients. Serum total

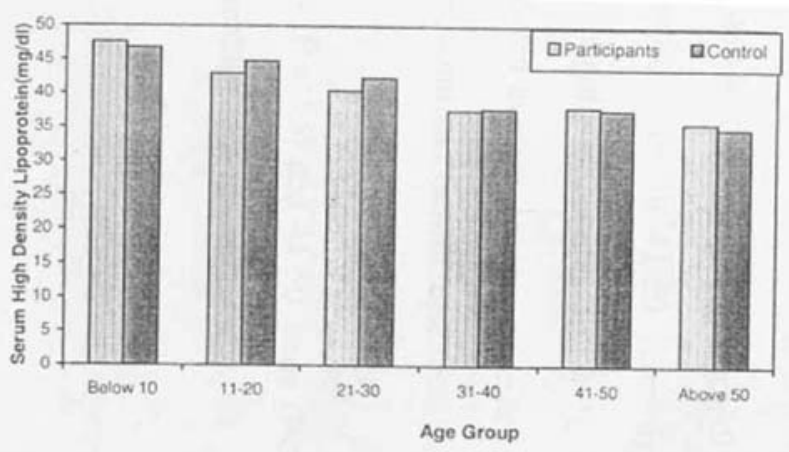

Fig. 5c: Serum high-density lipoprotein level of the Vitiligo patients and controls. The longest bar indicates the highest serum high-density lipoprotein level was observed in 41-50 years age group and above 50 years age group (around $38 \mathrm{mg} / \mathrm{dl}$ ) and no significant change of the serum high-density lipoprotein level was observed in the others age group as compare to the controls. The black bar indicates the controls and the white bar indicates the participants with Vitiligo protein estimation were also carried out of all Vitiligo patients in this study. This study represent that the total protein of the below 10 and 11-20 years age group patients were the significantly changed as compared to the controls, which is clinically very important.

Alanine aminotransferase (ALT)/SGPT, Alkaline phosphatase (ALP) and Asparate aminotransferase (AST) are serum enzymes are important marker for liver and heart disease. The result obtained from this biochemical analysis indicated that there were no significant changes occurred of these enzymes level compared with the healthy controls (shown in Fig. 4a and Table 4b). As results, it is clearly exhibited that liver disease or heart disease do not associated with Vitiligo. It is noted that tyrosinase is an enzyme that participate in the processing of melain production in normal melanocytes and melanoma cells, therefore the detection of tyrosinase in some patients with melanoma disease, which is also associated with the appearance in Vitiligo patients (Fishman et al. 1997).

Serum cholesterol, triglyceride (TG) and serum high-density lipoprotein (HDL) has interrelation in the synthesis of their endogenous system. Serum cholesterol and serum triglyceride were significantly changed in the age group of 31-40 years. In above 50 years age group the serum cholesterol and

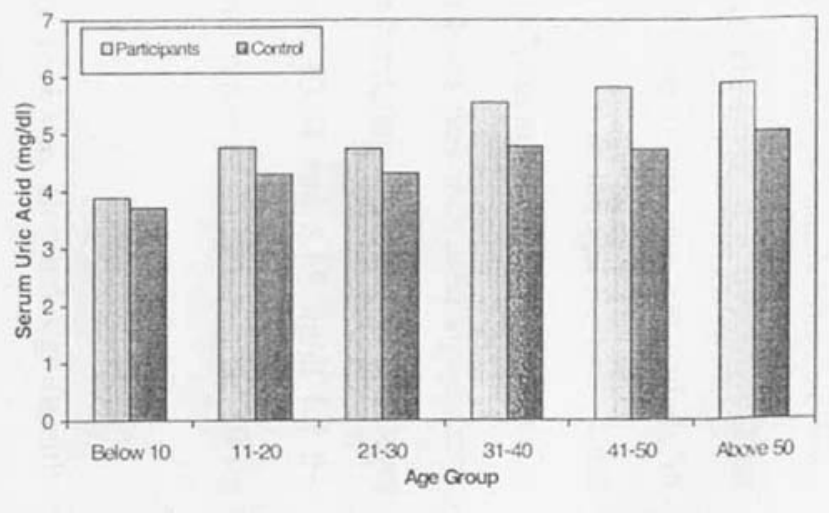

Fig. 5d: Serum uric acid level of the Vitiligo patients and controls. The longest bar indicates the highest serum uric acid level was observed in 41-50 years age group and above 50 years age groups. The black bar indicates the controls and the white bar indicates the participants with Vitiligo 
triglyceride (TG) level increased as compared with their controls (shown in Table Va, Vb and Fig. 5a, 5b). However, there were no significant changed occur in high-density lipoprotein (HDL) (Table Vc and Fig. 5c).

The difference of values of total serum uric acid between the control group and the study group of the Vitiligo patients was markedly and statistical analysis by the unaired t-test showed that $\mathrm{p}<0.05$. Therefore the markedly elevation observed in serum uric acid in 11-20 years age group patients was also statistically significant (shown in Table Vd and Fig. $5 d)$.

From this biochemical investigations it is reported that there was no significant changed observed in some biochemical parameters of the Vitiligo patients. But the serum urea, creatinine and uric acid level of the Vitiligo patients was slightly changed as compared to the control individuals.

\section{Conclusion}

In this study, the analysis of some biochemical parameters could be helpful for the physician to know about the pathological condition of the Vitiligo patients.

\section{Acknowledgement}

The skin and venereal disease department of Rajshahi Medical College Hospital, Bangladesh and Instituted of Biological Science, Rajshahi university, Bangladesh.

\section{References}

Amin MZ, Rahman MH and Hassan P 2008. Thyroid function in Bangladeshi patients with Vitiligo( Sheti). $J$. bio-sci. 16: 101-103.

Alkhateeb A Fain PR, Thody A, Bennett D and Spritz RA 2003. Epidemiology of Vitiligo and associated autoimmune disease in Causasian probands and their families. Pigment Cell Res. 16: 208-214.

Barnes L 1988. Vitiligo and the Vogt-Koyanagi-Harada syndrome. Dermatol Clin. 6: 229-239.

Bessou S, Gauthier Y, Surleve-Bazeille-JE, Pain C and Taieb A 1997. Epidermal reconstructs in Vitiligo an extrin- sic factor is needed to trigger the diseases. Br. J. Dermatol. 137(6): 889-897.

Burnes-Cox CJ and Pearson JEG 1972. Addisons disease, Vitiligo and multiple autoantibodies. Postgrad Med J. 48: $115-126$.

Bolognia JL and Pawelek JM 1988. Biology of hypopigmentation. J. Am Acad Dermatol. 19: 217-225.

Bystryn JC, Rigel D, Friedman RJ and Kopf A 1987. Prognostic significance of hypopigmentation in malignant melanoma. Arch Dermatol. 123: 1053-1055.

Dawber RPR 1970. Clinical association of Vitiligo. Postgrad Med J. 46: 276-282.

Fishman P, Merimisk O, Baharav E and Shoenfield Y 1997. Autoantibodies to tyrosinase the bridge between melanoma and Vitiligo. Cancer. 79(8):1461-1464.

Ghoneum M, Grimes PE, Gill G and Kelly AP 1987). Natural cell-mediated cytotoxicity in Vitiligo. $\mathrm{J}$. Am Acad Dermatol. 17: 600-605.

Grimes P. E, Ghoneum M.and Stockton T et al. 1986. T cell profiles in Vitiligo. J Am Acad Dermatol. 14: 196-201.

Howanitz N, Nordlund JL, Lerner AB and Bystryn JC. 1981. Antibodies to melanocytes occurrence in patients with Vitiligo and chronic mucocutaneous candidiasis. Arch Dermatol. 117: 705-708.

Hann SK and Lee HJ 1996. Segmental Vitiligo: Clinical findings in 208 patients. J. Am Acad. Dermatol. 35: 671-676.

Lerner AB and Kirkwood J M 1984. Vitiligo and melanoma: Can genetically abnormal Melanocytes result in both Vitiligo and melanocytes result in both

Vitiligo and Melanoma within a single family. J Am Acad Dermatol. 11: 696-701.

Lacovelli P, Sinagra JL, Vidiolin AP, Marendas, Caitanio B and Leone G 2003. Relevance of thyroiditis and of other autoimmune diseases in children with Vitiligo. 
Dermatology. 210: 26-30.

Nordlund JJ 1987. Hypopigmentation, Vitiligo and melanoma. New data, more enigmas. Arch Dermatol. 123: $1005-1008$.

Ortonne-J.P and Bose-SK 1993. Vitiligo: Where we stand? Pigment-Cell - Res. 6(2): 61-72.
Ongenaek Geel NV and Naeyaen JM 2003. Evidence for an autoimmune pathogenesis of Vitiligo. Pigment Cell Res. 16: 90-96.

Thomas B Fitztrick, Jeffery D Bernhard and Thomas G Croley 1999. The structure of skin Lesions and Fundamentals of Diagnosis. Dermatology in general medicine by McGraw-Hill Companies, Inc.5th ed. USA.550-554.

Manuscript received on 08 June 2010; revised on 13 July 2011; accepted on 13 October 2011. 